\title{
IMPROVEMENT OF RATING METHODOLOGY
}

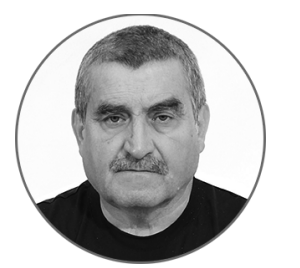

\author{
Petr N. BRUSOV
}

Financial University under Government of Russian Federation, Moscow, Russian Federation pnb1983@yahoo.com

Corresponding author

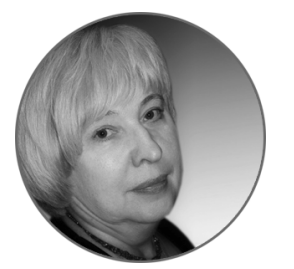

\section{Tat'yana V. FILATOVA}

Financial University under Government of Russian Federation, Moscow, Russian Federation tvfilatova@fa.ru

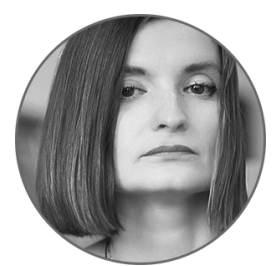

\section{Natal'ya P. OREKHOVA}

Southern Federal University, Rostov-on-Don, Russian Federation fet_mir@bk.ru

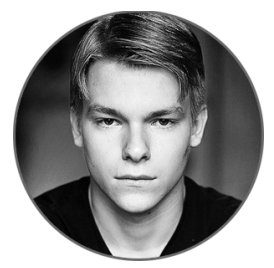

\section{Veniamin L. KULIK}

Financial University under Government of Russian Federation, Moscow, Russian Federation venya.kulik@mail.ru

\section{Article history:}

Received 6 February 2018 Received in revised form 20 February 2018 Accepted 6 March 2018 Translated 21 May 2018 Available online 27 June 2018

JEL classification: $\mathrm{G} 24, \mathrm{G} 32$

Keywords: rating, rating methodology, Brusov-Filatova-Orekhova theory, BFO theory, coverage ratio, leverage ratio

\section{Abstract}

Importance The article focuses on rating methodologies, their drawbacks and improvement methods. Objectives The research generalizes the new approach to the rating methodology adjusting it for the Brusov Filatova - Orekhova modern theory of capital cost and capital structure in relation to corporations of any age.

Methods The research is based on the Brusov - Filatova - Orekhova modern theory of capital cost and capital structure (BF0 theory).

Results The article analyzes methodological and systemic drawbacks of the existing credit ratings of non-financial issuers. We incorporate financial ratios used for rating into the general case of the BFO theory. The article also examines how the Weighted Average Cost of Capital depends on coverage and leverage ratios.

Conclusions and Relevance The proposed approach will make ratings more accurate and unbiased. The findings may prove useful to international and Russian rating agencies to evaluate the solvency of issuers.

C) Publishing house FINANCE and CREDIT, 2018

The editor-in-charge of this article was Irina M. Vechkanova

Authorized translation by Irina M. Vechkanova 


\section{Introduction}

In our previous article, we set out a conceptually new approach to the rating methodology. It provides for an appropriate application of discounting to cash flows, which is almost neglected in the existing rating methodologies, use of rating ratios while discounting, correct assessment of discount rates in line with financial ratios. The research delved into the perpetuity limit of the Brusov - Filatova - Orekhova modern theory of capital cost and capital structure (BFO theory), which was modified for rating purposes.

As noted in researches referred to hereinafter [1-27], the Modigliani-Miller theorem, the perpetuity limit of the BFO theory, underestimates the cost of capital, thus resulting in overstated estimates of the corporate capitalization. Furthermore, the perpetuity limit fails to account for a timing factor, which is very critical. Hence it omits the concept of corporate age, the life cycle of a company being taken as indefinite (perpetuity).

In this research, we generalize the earlier proposed approach $^{1}$ and fit it to the BFO theory and corporations of arbitrary age, i.e. a general case of the BFO theory. This made us considerably modify the BFO theory, which is much more complex than the perpetuity limit ${ }^{2}$, since the concept of leverage in financial management (a ratio of loan to equity) substantially differs from the leverage in rating practices (a ratio of loan, loan interests to various amounts of generated income) and inverse ratios are used (ratios of different amounts of generated income to loan or loan interests), i.e. the so called coverage ratios (debt, interests).

If modified for rating purposes, the BFO theory allows to adequately discount financial flows at correct discount rates, in accordance with rating ratios while discounting, and timing factor, which is missing on the perpetuity limit, through being critical. Therefore, the company's age (as per BFO-1) or its life cycle (BFO-2) shall be taken into consideration.

${ }^{\dagger}$ For the source article, please refer to: Брусов П.Н., Филатова Т.В., Орехова Н.П., Кулик В.Л. Совершенствование методологии рейтингования. Финансы и кредит. 2018. Т. 24. № 3. С. 652-678. URL: https://doi.org/10.24891/fc.24.3.652

${ }^{1}$ Brusov P.N., Filatova T.V., Orekhova N.P., Kulik V.L. [Incorporation of rating parameters into the perpetuity range of the Brusov-FilatovaOrekhova modern theory of capital structure]. Finansy $i$ kredit $=$ Finance and Credit, 2017, vol. 23, no. 40, pp. 2378-2397.

URL: https://doi.org/10.24891/ fc.23.40.2378 (In Russ.)

${ }^{2}$ Ibid.

\section{Existing Credit Rating of Non-Financial Issuers: Analysis of Methodological and Systemic Weaknesses}

We analyzed methodological and systemic weaknesses of the existing credit rating of non-financial institutions, covering the methodologies of the Big Three credit rating agencies (Standard \& Poor's, Fitch and Moody's) and national rating agency.

\section{Discounting}

Despite being ample and detailed, the existing rating methodologies do still have many drawbacks. As mentioned in our previous research, what inter alia impairs all the rating methodologies is that they do not arrange for discounting or envisage it for a very narrow usage. Even if the discounting procedure is in place, it is performed not quite correctly since the discount rate is erroneously chosen to discount cash flows. The timing factor shall evidently be taken into consideration because it relates to the time value of money. In the financial part of the rating process, proceeds (generated income) are compared with debt and interests paid. Whereas there is a time gap between the moment income is received and debt and interests are repaid, the discounting proves to be vital to compare the income, debt and interest and assign appropriate credit ratings to issuers. Hence it raises the question about the discount rate used. The question has always been on the agenda and complicated in many aspects, i.e. corporate finance, investment, business valuation, where it is especially important as even a slight change in the discount rate significantly influences the company's capitalization. Mala fide appraisers make use of it for making companies artificially bankrupt. The question is also crucial in rating practices in assigning credit ratings to issuers and forecasting.

Hence once financial flows are concerned, discounting shall be taken into account. Otherwise, the time value of money is neglected. Therefore, discounting shall be an inevitable aspect to consider as part of analysis of financial flows.

Discounting shall be taken into account, when rating practices require that financial statements for a three or five years' time are used (under GAAP), assuming the flat behavior of indicators outside the purview of the period. 


\section{Dividend Policy of Company}

Dividend policies shall be kept in mind for rating purposes since ratings always refer to financial policies. However, the existing rating methodologies evaluate the stability of dividend policies only, without questioning its reasonableness and correspondence of dividends paid with their economically adequate amount.

Dividend policies are evaluated by comparing the amount of dividends paid and their economically adequate amount, that is the cost of the company's equity. The cost of equity is rather difficult to calculate. The BFO theory allows to adequately evaluate the cost of equity and hereby compare the amount of dividends paid by the company with their economically adequate amount. Therefore, the reasonableness of dividend policies is reviewed, which definitely relates to the creditworthiness of the issuer.

For instance, discretionary cash flow (DCF, S\&P) shall be compared with the economically adequate amount, thus influencing the rating.

\section{Leverage Level}

Currently, rating agencies refer to leverage $(L=D / S)$ solely to evaluate the financial stability and bankruptcy risk. In fact, it influences the principle financial indicators of corporate performance, i.e. the cost of equity, WACC. In other words, it has an impact on the cost of fundraising and capitalization. If this impact is overlooked as part of financial reporting analysis, this will lead to incorrect conclusions.

Investment projects and investment programs of companies can be rated in accordance with the effect of leveraged finance, which is assessed by the BFO theory, on the efficiency of investment projects for various cost of capital.

\section{Taxation}

Taxation significantly influences issuers' ratings. Companies and their investment programs can be assigned ratings in accordance with the effect of taxation (corporate income tax rate) on financial results of the company, efficiency of investment projects, which is assessed by the BFO theory. In case of changes in the corporate income tax rate, the assessments also apply to forecast estimates and analysis of the country risk.

Forecasts and analysis of the country risk can be based on the effect of the base interest rate of the Central Bank of Russia, loan interest rates of commercial banks on the efficiency of investment projects, creation of the favorable investment climate in the country, which is assessed by the BFO theory.

\section{Attention to Sectoral Distinctions of the Issuer}

The existing rating methodologies provide for sectoral distinctions of the issuers, especially in case of newly incorporated businesses drawing upon predecessors' experience. As per the ACRA Methodology for Credit Ratings Assignment to Regional and municipal Authorities of the Russian Federation, the company's creditworthiness shall be determined in line with sectoral distinctions of the company. To assess the sectoral risk factor, ACRA classifies sectors into five groups by their cyclicity, entry barrier, sectoral risk statistics, development trend and prospect. The sectoral risk profile factor is weighted individually for each group, varying by credit risk level. This creates the ceiling of ratings for companies operating in sectors with high risk exposure, providing premiums to sectors with lower risk exposure.

However, sectoral distinctions of issuers obviously need to be considered more thoroughly. Rating methodologies shall focus on sectoral distinctions of issuers' financial flows more profoundly. In particular, it is very important to determine whether the entity needs working capital, which directly contributes to financial stability, solvency and creditworthiness. The latter is a key metric in rating.

\section{Inattention to Issuer's Distinctions}

The existing methodologies disregard the issuer's salience, specifics of its financial reporting, taxation, regulatory and financial systems, sacrificing it to a full comparability of financial reports and smoothing the differences (Moody's).

\section{Financial Ratios}

How many financial ratios are needed? How many ratios would be enough? What particular financial ratios shall be in place? Such questions seem to have been left behind. However, the quantity and quality of financial ratios, their correlation or independence significantly determine the financial risk and state of the issuer.

Some ratios fail to give a definite view of the issuer. For example, the cash flow to leverage ratio is high no matter whether cash flow is high or leverage is low. The thing is that to what extent the two states of the issuer equally correlate with the credit risk, considering that there are associated with the same financial risk. 
As admitted in the ACRA methodology, in certain cases some characteristics of a factor/subfactor may formally be attributed to several categories for evaluation, being typical of qualitative factors. In such circumstances, rating is assigned on the basis of expert opinion accounting for the most crucial parameters.

In this respect, it is worth mentioning that it is of paramount importance inter alia to formalize experts' opinions in order to improve the rating methodology and hereby make the expert judgment more unbiased and reliable. There may be several options to address the issue, i.e. the use of the modern measurement theory and its results, reliance on the formalism of fuzzy sets and fuzzy logic, etc.

Tabulating the composition of different risks (for instance, in Corporate Industry and Country Risk Assessment - CIRCA (S\&P methodology) results in a 6x6 matrix comprising 36 elements. That is, CICRA shall have 36 different values, but their total number is 6 . Is that reasonable? We believe it is evidence of unreasonableness or existence of other reasons, but they should be very well substantiated.

We may refer to a myriad of identical cases. Indeed, as per the ACRA Methodology for Credit Ratings Assignment to Microfinancial Organizations on the National Scale for the Russian Federation, Table 1 presents a $5 \times 5$ matrix comprising 25 elements, i.e. there shall be 25 different states, but only five states are observed. The same question of reasonableness arises. The presence of the five states indicates the lack of reasonableness.

As per S\&P methodology, compositions of different ratios have been tabulated not quite correctly so as to determine the financial risks:

- FFO/debt(\%), Debt/EBITDA(x), FFO/cash interest $(x)$, EBITDA/interest $(x), \quad$ CFO/debt(\%), FOCF/debt(\%), DCF/debt(\%);

- minimal: $60+$, Less than 1.5, More than 13, More than 15, More than 50, 40+, 25+;

- modest: 45-60, 1.5-2, 9-13, 10-15, 35-50, 25-40, 1525;

- intermediate: 30-45, 2-3, 6-9, 6-10, 25-35, 15-25, 10-15:

- significant: 20-30, 3-4, 4-6, 3-6, 15-25, 10-15, 5-10;

- aggressive: 12-20, 4-5, 2-4, 2-3, 10-15, 5-10, 2-5;
- highly leveraged: less than 12, greater than 5, less than 2 , less than 2 , less than 10 , less than 5 , less than 2.

The relations are at least not correlated completely, being used as such though. So, we can see that the two line Minimal and Models do not let parameters of the lines mix, though such cases are quite possible. For example, 60+, 1,5-2, More than 13, More than 15, More than $50,40+, 25+$.

Such aspects constrain the applicability of rating agencies' methods. Rating agencies adopt them in order to simplify the rating procedure, intentionally or not, and unify methods for various systems of financial reporting, countries, for purposes of comparable results.

The said ambiguity of assessments has already been noticed when assigning ratings to Gazprom (S\&P).

\section{Modification of the BFO Theory for Corporations of Arbitrary Age for Rating Purposes}

We hereinafter modify the BFO theory for corporations of arbitrary age for rating purposes. This appears to be a much more complicated task than the modification of the perpetuity limit of the BFO theory.

The BFO formula proves to be inapplicable in this case [1]:

$$
\frac{\left[1-(1+W A C C)^{-n}\right]}{W A C C}=\frac{\left[1-\left(1+k_{0}\right)^{-n}\right]}{k_{0}\left[1-\omega_{d} T\left(1-\left(1+k_{d}\right)^{-n}\right)\right]} .
$$

The formula does not account for cash flows CF and loan $D$, while the leverage level $L=D / S$ (as though it is understood in financial management) is presented only through the percentage of borrowings $w d=L /(L+1)$.

To modify the BFO general theory for rating purposes, we shall refer to initial assumptions underlying the BFO formula.

According to the Modigliani-Miller theorem providing for corporate taxes [3-5], which we generalize [1] for the final period of time, i.e. companies and corporations of arbitrary age, the capitalization of a leveraged company, which uses debt financing, $V_{L}$ equals that of a non-leveraged company, which is free from debt financing $V_{0}$, plus a tax shield amount for the final period of time $T S_{n}$. 


$$
V_{L}=V_{0}+T S_{n},
$$

where the capitalization of a financially dependent company is as follows:

$$
V_{L}=\frac{C F}{W A C C}\left(1-(1+W A C C)^{-n}\right) \text {; }
$$

capitalization of a financially independent company is as follows:

$$
V_{0}=\frac{C F}{k_{0}}\left(1-\left(1+k_{0}\right)^{-n}\right) \text {; }
$$

and the tax shield for $n$ years:

$$
T S_{n}=t D\left(1-\left(1+k_{d}\right)^{-n}\right) \text {. }
$$

$C F$ is income for the period, $D$ is an amount of loan, $k_{d}$ is the loan interest rate, $k_{0}$ is the cost of the financially independent's equity and $n$ is the company's age.

Inserting the formulas (2)-(4) into (1), we get the formula (5), which will be used subsequently to modify the BFO theory for rating purposes:

$$
\begin{aligned}
& \frac{C F\left(1-(1+W A C C)^{-n}\right)}{W A C C}=\frac{C F}{K_{0}}\left(1-\left(1+k_{0}\right)^{-n}\right)+ \\
& +t D\left(1-\left(1+k_{d}\right)^{-n}\right) .
\end{aligned}
$$

Let us call the equation (5) the BFO-3 model (the BFO theory for rating purposes). BFO-1 applies to companies of the ultimate age remaining in the market, while BFO-2 refers to those ones of the final life cycle that left the market [1]. Afterwards we make the first attempt to incorporate rating parameters into the BFO modern theory of capital cost and capital structure ${ }^{3}$.

In this research, two types of rating ratios are considered, i.e. coverage ratios and leverage ratios.

We suggest starting with debt coverage ratios and respective interests.

\section{Coverage Ratios}

We examine three types of coverage ratios, i.e. debtservice coverage ratio, interest coverage ratio and debtand-interest coverage ratio. Please note that we introduced the latter type of the coverage ratios for the first tome to more comprehensively describe the issuer's ability to pay off debts and respective interests.

\footnotetext{
${ }^{3}$ Brusov P.N., Filatova T.V., Orekhova N.P., Kulik V.L. [Incorporation of rating parameters into the perpetuity range of the Brusov-FilatovaOrekhova modern theory of capital structure]. Finansy $i$ kredit = Finance and Credit, 2017, vol. 23 , no. 40 , pp. 2378-2397.

URL: https://doi.org/10.24891/ fc.23.40.2378 (In Russ.)
}

\section{Debt-Service Coverage Ratio}

Dividing the both parts of the formula (5) by the loan $D$, we introduce the debt-service coverage ratio into the BFO general theory:

$$
\frac{C F}{D}=i_{1} ;
$$

$$
\begin{aligned}
& i_{1} A=i_{1} B+t C \\
& \frac{i_{1} *\left(1-(1+W A C C)^{-n}\right)}{W A C C}=\frac{i_{1}\left(1-\left(1+k_{0}\right)^{-n}\right)}{k_{0}+t\left(1-\left(1+k_{d}\right)^{-n}\right)} .
\end{aligned}
$$

Therefore,

$$
\begin{aligned}
& A=\frac{\left(1-(1+W A C C)^{-n}\right)}{W A C C} ; \\
& B=\frac{\left(1-\left(1+k_{0}\right)^{-n}\right)}{k_{0}} ; \\
& C=\left(1-\left(1+k_{d}\right)^{-n}\right)
\end{aligned}
$$

The coverage ratio $i_{1}$ can be used to assess such rating parameters as DCF/Debt, FFO/Debt, CFO/Debt, FOCF/Debt, etc.

The following denotations are used:

EBITDA stands for earnings before interests, taxes, depreciation and amortization;

EBITDAR stands for earnings before interests, taxes, depreciation, amortization and restructuring or rent costs;

FFO stands for operating cash flows before changes in working capital;

Debt is the outstanding amount;

CFF is cash flows from financing activities;

FCF is free cash flow;

NFCF is net cash flow;

$D C F$ is discounted cash flow;

CFO is cash flow from operations.

We suggest analyzing the dependence of WACC on the debt-service coverage ratio $i_{1}$ for companies aged $n=3$ and $n=5$ provided that $k_{0}=8 \% ; k_{d}=4 \% ; t=20 \% ; i_{1}$ ranges from 0 to 10 .

Fig. 1 and 2 depict the dependence of WACC on the coverage ratio $i_{1}$. 


\section{Interest Coverage Ratio}

We suggest analyzing the dependence of WACC on the loan interest coverage ratio $i_{2}$. Dividing both parts of the formula (5) by the amount of loan interests $k_{d} D$, we introduce the loan interest coverage ratio $i$ into the BFO general theory.

$$
\begin{aligned}
& i_{2}=\frac{C F}{k_{d} D} . \\
& i_{2} A=i_{2} B+\frac{t C}{k_{d}} . \\
& \frac{i_{2}\left(1-(1+W A C C)^{-n}\right)}{W A C C}=\frac{i_{2}\left(1-\left(1+k_{0}\right)^{-n}\right)}{k_{0}}+ \\
& +\frac{t\left(1-\left(1+k_{d}\right)^{-n}\right)}{k_{d}} .
\end{aligned}
$$

The loan interest coverage ratio $i_{2}$ is used to assess such rating parameters as FFO/cash interest, EBITDA/interest, etc.

Based on the equation (6), we study the dependence of WACC on the loan interest coverage ratio $i_{2}$ for companies at age three $(n=3)$ and five $(n=5)$.

Fig. 3 and 4 depict the dependence of WACC on the loan interest coverage ratio $i_{2}$.

\section{Debt-and-Interest Coverage Ratio}

The next step is to scrutinize the dependence of WACC on the debt-and-interest coverage ratio $i_{3}$. Please note that we introduced this ratio for the first time to more comprehensively describe the issuer's ability to pay off debts and respective interests.

Dividing the both parts of the formula (5) by the amount of debt and interests $\left(1+k_{d}\right) D$, we insert the debt-andinterest coverage ratio into the BFO general theory.

$$
\begin{aligned}
& \frac{C F}{D\left(1+k_{d}\right)}=i_{3} . \\
& i_{3} A=i_{3} B+\frac{t C}{1+k_{d}} . \\
& \frac{i_{3}\left(1-(1+W A C C)^{-n}\right)}{W A C C}=\frac{i_{3}\left(1-\left(1+k_{0}\right)^{-n}\right)}{k_{0}}+ \\
& +\frac{t *\left(1-\left(1+k_{d}\right)^{-n}\right)}{1+k_{d}} .
\end{aligned}
$$

Based on the equation (7), we examine the dependence of WACC on the debt-and-interest coverage ratio $i_{3}$ for companies at age three $(n=3)$ and five $(n=5)$.

Fig. 5 and 6 depict the dependence of WACC on the debt-and-interest coverage ratio $i_{3}$.

Fig. 7 and 8 show the dependence of WACC on the debt coverage ratio, interest coverage ratio and debt-andinterest coverage ratio totally.

Conclusions. Having analyzed Tables 2-4 and Fig. 1-5, we see WACC increase as debt coverage ratios $i_{1}, i_{2}, i_{3}$ grow in all the companies of any age. We considered those ones at age three and five. However, companies of other age are obvious to face a similar situation. The more debt coverage ratios grow, the more WACC values converge. $W A C C\left(i_{1}\right)$ and $W A C C\left(i_{3}\right)$ are close to one another, albeit not being equal, but $\operatorname{WACC}\left(i_{2}\right)$ significantly differs from them. These conclusions stem from a low interest rate on the loan $k_{d}$, an increase of which will make $\operatorname{WACC}\left(i_{1}\right)$ and $\operatorname{WACC}\left(i_{3}\right)$ more divergent, while $W A C C\left(i_{2}\right)$ becomes less different from them. Curves of dependencies $W A C C\left(i_{j}\right)$ for older companies are located higher. If we compare the results with cases of perpetuity companies ${ }^{4}$, it is evident that curves of dependencies $W A C C\left(i_{j}\right)$ reach the saturation point more smoothly in case of companies at definite age, than in case of perpetuity companies, where they reach the saturation point provided coverage ratios are about 1. This is certainly true for $\operatorname{WACC}\left(i_{1}\right)$ and $\operatorname{WACC}\left(i_{3}\right)$, while $W A C C\left(i_{2}\right)$ smoothly depends on the interest coverage ratio even within the perpetuity limit. As a result, real (rather than perpetuity) companies need to assess dependencies of $\operatorname{WACC}\left(i_{j}\right)$ in case of companies of definite age and apply them as discount rates to financial flows for rating purposes.

\section{Leverage Ratios}

This part of the research is devoted to three types of leverage ratios, i.e. the leverage ratio of the loan (debt), leverage ratio of loan interests and leverage ratio of debt and interests. We hereinafter analyze how WACC depends on leverage ratios $\left(I_{1}, I_{2}, I_{3}\right)$ in case of companies at age three and five and cost of capital accounting for $k_{0}=10 \%, k_{d}=6 \%$ under $t=20 \%$, with leverage ratios $l_{i}$ ranging from 0 to 10 .

\footnotetext{
${ }^{4}$ Brusov P.N., Filatova T.V., Orekhova N.P., Kulik V.L. [Incorporation of rating parameters into the perpetuity range of the Brusov-FilatovaOrekhova modern theory of capital structure]. Finansy $i$ kredit $=$ Finance and Credit, 2017, vol. 23, no. 40, pp. 2378-2397. URL: https://doi.org/10.24891/ fc.23.40.2378 (In Russ.)
} 


\section{Leverage Ratio of Debt}

As per the BFO theory, the dependence of WACC on the leverage ratio of debt $l_{1}$ is expressed with the following formula:

$$
\begin{aligned}
& \frac{\left(1-(1+W A C C)^{-n}\right)}{W A C C}-\frac{\left(1-\left(1+K_{0}\right)^{-n}\right)}{K_{0}}- \\
& -t\left[1-\left(1+K_{d}\right)^{-n}\right] l_{1}=0,
\end{aligned}
$$

where $l_{1}=\frac{D}{C F}$,

where $I_{1}$ is the leverage ratio of debt;

$t$ is the corporate income tax rate;

$k_{0}$ is the cost of a non-leveraged (financially independent) company's equity;

$k_{d}$ is the cost of debt;

$\mathrm{n}$ is age of a company;

$C F$ is income for the period;

$D$ is the amount of debt.

This ratio can be used to assess such rating parameters as Debt/EBITDA, etc.

We make a table visualizing the dependence of WACC on I.

Fig. 9 and 10 illustrate the dependence of WACC on the leverage ratio of debt (I1) in case of companies at age $3(n=3)$ and five $(n=5)$ respectively.

\section{Leverage Ratio of Loan Interests}

As per the BFO theory, the formula below expresses the dependence of WACC on the leverage ratio of loan interest $I_{2}$ :

$$
\begin{aligned}
& \frac{\left(1-(1+W A C C)^{-n}\right)}{W A C C}-\frac{\left(1-\left(1+K_{0}\right)^{-n}\right)}{K_{0}}- \\
& -\frac{\left(t \cdot l_{2}\left[1-\left(1+K_{d}\right)^{-n}\right]\right)}{K_{d}}=0,
\end{aligned}
$$

where $l_{2}=\frac{K_{d} D}{C F}$;

$K_{d} D$ stands for loan interests in kind.

Let us measure the dependence of WACC on the leverage ratio of loan interests $I_{2}$.

Fig. 11 and 12 illustrate the dependence of WACC on the leverage ratio of loan interests $I_{2}$ as per the BFO theory in case of companies at age three $(n=3)$ and five $(n=5)$ respectively.

As per the BFO theory, the dependency of WACC on the leverage ratio of debt and interests $I_{2}$ is expressed with the following formula:

$$
\begin{aligned}
& \frac{\left(1-(1+W A C C)^{-n}\right)}{W A C C}-\frac{\left(1-\left(1+K_{0}\right)^{-n}\right)}{K_{0}}- \\
& -\frac{t \cdot l_{3}\left[1-\left(1+K_{d}\right)^{-n}\right]}{K_{d}+1}=0,
\end{aligned}
$$

where $l_{3}=\frac{\left(k_{d}+1\right) D}{C F},\left(k_{d}+1\right) D$ is the amount of debt and respective interests.

We make a table visualizing the dependence of WACC on I3.

Fig. 13 and 14 illustrate the dependence of WACC on the leverage ratio of debt and interest 13 as per the BFO theory in case of companies at age three $n=3$ and five $n=5$.

Fig. 15 and 16 depicts consolidated graphs of the dependency of WACC on $I_{1}, I_{2}, I_{3}$ in case of $n=3$ and $n=5$.

Conclusions. Having analyzed Tables 5-7 and Fig. 6-16, we concluded that the higher the leverage ratios $l_{1}, l_{2}, l_{3}$ in case of company of any age (we consider companies at age three and five, but the situation will definitely be identical in case of companies of other age), the lower WACC. The more the leverage ratios grow, the more divergent WACC-values (they spring from the point $(0, k))$. WACC $\left(I_{1}\right)$ and $\operatorname{WACC}\left(I_{3}\right)$ are close to one another, albeit not being equal, decreasing almost in a linear way as the leverage ratios increase. The dependence of $W A C C\left(I_{2}\right)$ significantly differs from $W A C C\left(I_{1}\right)$ and $W A C C\left(I_{3}\right)$. Both conclusions stem from a low interest rate on loan $k_{d}$, an increase of which will make $\operatorname{WACC}\left(I_{1}\right)$ and $\operatorname{WACC}\left(I_{3}\right)$ more divergent, while $\operatorname{WACC}\left(I_{3}\right)$ becomes less different from them. Curves of dependencies of $W A C C\left(l_{j}\right)$ for older companies run higher, signifying their slower decrease. If we compare the results with cases of perpetuity companies ${ }^{5}$, it is evident that the negative slope coefficient of dependencies of $\operatorname{WACC}\left(l_{j}\right)$ is more than twice as high (by

\footnotetext{
${ }^{5}$ Brusov P.N., Filatova T.V., Orekhova N.P., Kulik V.L. [Incorporation of rating parameters into the perpetuity range of the Brusov-FilatovaOrekhova modern theory of capital structure]. Finansy $i$ kredit $=$ Finance and Credit, 2017, vol. 23, no. 40, pp. 2378-2397.

URL: https://doi.org/10.24891/ fc.23.40.2378 (In Russ.)
} 
module) as the identical slope coefficient of companies with definite age. It means that $\operatorname{WACC}\left(I_{j}\right)$ decreases faster in case of companies with definite age that in perpetuity cases $^{6}$.

\section{Conclusion}

In this research, we analyzed methodological and systemic drawbacks of the way ratings are assigned to non-financial issuers. We modified the Brusov-FilatovaOrekhova modern theory of capital cost and capital structure for rating purposes. As part of the modified BFO theory, we incorporated financial ratios used for rating purposes (rating ratios) into the general case of the BFO theory. We investigated the dependence of WACC on two types of rating ratios, i.e. coverage ratios and leverage ratios, and substantiated the importance of discounting for rating of issuers.

Following the devised method for assessing discount rates in line with rating ratios, it is possible to apply correct discount rates to financial flows for rating purposes. The findings of the two researches we presented herein allow to bridge a gap between fundamental theories of capital structure and rating methodologies. Methods of well elaborated and verified theories open new opportunities for the rating sector, enabling it to abandon the qualitative method of creditworthiness evaluation and opt for quantitative ones, thus enhancing the quality and accuracy of ratings. Both researches we release herein frame a new approach to rating methodologies.

\footnotetext{
${ }^{6}$ Ibid.
} 
Table 1

Assessment of funding and liquidity

\begin{tabular}{|c|c|c|c|c|c|}
\hline \multirow[t]{2}{*}{ Funding assessment } & \multicolumn{5}{|c|}{ Liquidity assessment } \\
\hline & 1 & 2 & 3 & 4 & 5 \\
\hline 1 & 1 & 2 & 2 & 3 & 4 \\
\hline 2 & 1 & 2 & 3 & 3 & 4 \\
\hline 3 & 2 & 2 & 3 & 4 & 5 \\
\hline 4 & 3 & 3 & 3 & 4 & 5 \\
\hline 5 & 3 & 3 & 4 & 5 & 5 \\
\hline
\end{tabular}

Source: Authoring based on the Analytical Credit Rating Agency (ACRA) data

\section{Table 2}

Dependence of WACC on $i_{1}$ for companies at age three $(n=3)$ and five $(n=5)$

\begin{tabular}{llllll}
\hline $\boldsymbol{t}$ & $\boldsymbol{k}_{\boldsymbol{0}}$ & $\boldsymbol{k}_{\boldsymbol{d}}$ & $\boldsymbol{i}_{\boldsymbol{1}}$ & $\boldsymbol{W A C C}(\boldsymbol{n}=\mathbf{3})$ & $\boldsymbol{W A C C}(\boldsymbol{n}=5)$ \\
\hline 0.2 & 0.08 & 0.04 & 1 & 0.075356711 & 0.07663868 \\
\hline 0.2 & 0.08 & 0.04 & 2 & 0.077705469 & 0.0783126 \\
\hline 0.2 & 0.08 & 0.04 & 3 & 0.078412717 & 0.0788732 \\
\hline 0.2 & 0.08 & 0.04 & 4 & 0.078808879 & 0.079154 \\
\hline 0.2 & 0.08 & 0.04 & 5 & 0.079046807 & 0.07932264 \\
\hline 0.2 & 0.08 & 0.04 & 6 & 0.079205521 & 0.07943518 \\
\hline 0.2 & 0.08 & 0.04 & 7 & 0.079318935 & 0.0795156 \\
\hline 0.2 & 0.08 & 0.04 & 8 & 0.079404022 & 0.07957594 \\
\hline 0.2 & 0.08 & 0.04 & 9 & 0.079470216 & 0.07962287 \\
\hline 0.2 & 0.08 & 0.04 & 10 & 0.07952318 & 0.07966043 \\
\hline
\end{tabular}

Source:Authoring

\section{Table 3}

Dependence of WACC on $i_{2}$ for companies at age three $(n=3)$ and five $(n=5)$

\begin{tabular}{llllll}
\hline $\boldsymbol{t}$ & $\boldsymbol{k}_{0}$ & $\boldsymbol{k}_{\boldsymbol{d}}$ & $\boldsymbol{i}_{2}$ & $\boldsymbol{W A C C}(\boldsymbol{n}=\mathbf{3})$ & $\boldsymbol{W A C C}(\boldsymbol{n}=5)$ \\
\hline 0.2 & 0.08 & 0.04 & 1 & -0.021238089 & 0.00793717 \\
\hline 0.2 & 0.08 & 0.04 & 2 & 0.02529016 & 0.04111354 \\
\hline 0.2 & 0.08 & 0.04 & 3 & 0.042483465 & 0.0533843 \\
\hline 0.2 & 0.08 & 0.04 & 4 & 0.051456351 & 0.05974575 \\
\hline 0.2 & 0.08 & 0.04 & 5 & 0.056965593 & 0.06365738 \\
\hline 0.2 & 0.08 & 0.04 & 6 & 0.060692181 & 0.06630611 \\
\hline 0.2 & 0.08 & 0.04 & 7 & 0.063380861 & 0.06821315 \\
\hline 0.2 & 0.08 & 0.04 & 8 & 0.065412245 & 0.06966377 \\
\hline 0.2 & 0.08 & 0.04 & 9 & 0.067001115 & 0.07078076 \\
\hline 0.2 & 0.08 & 0.04 & 10 & 0.068277865 & 0.07168658 \\
\hline
\end{tabular}

Source:Authoring 


\section{Table 4}

Dependence of WACC on $i_{3}$ for companies at age three $(n=3)$ and five $(n=5)$

\begin{tabular}{llllll}
\hline $\boldsymbol{t}$ & $\boldsymbol{k}_{\mathbf{0}}$ & $\boldsymbol{k}_{\boldsymbol{d}}$ & $\boldsymbol{i}$ & $\boldsymbol{W A C C}(\boldsymbol{n}=\mathbf{3})$ & $\boldsymbol{W A C C}(\boldsymbol{n}=5)$ \\
\hline 0.2 & 0.08 & 0.04 & 1 & 0.075536724 & 0.07676703 \\
\hline 0.2 & 0.08 & 0.04 & 2 & 0.077796177 & 0.07837722 \\
\hline 0.2 & 0.08 & 0.04 & 3 & 0.078473634 & 0.07891638 \\
\hline 0.2 & 0.08 & 0.04 & 4 & 0.078854621 & 0.07918642 \\
\hline 0.2 & 0.08 & 0.04 & 5 & 0.079083426 & 0.07934861 \\
\hline 0.2 & 0.08 & 0.04 & 6 & 0.079236052 & 0.07945683 \\
\hline 0.2 & 0.08 & 0.04 & 7 & 0.079345114 & 0.07953417 \\
\hline 0.2 & 0.08 & 0.04 & 8 & 0.079426934 & 0.07959218 \\
\hline 0.2 & 0.08 & 0.04 & 9 & 0.079490586 & 0.07963732 \\
\hline 0.2 & 0.08 & 0.04 & 10 & 0.079541516 & 0.07967343 \\
\hline
\end{tabular}

Source:Authoring

Table 5

Dependence of WACC on $l_{1}$ for companies at age three $(n=3)$ and five $(n=5)$

\begin{tabular}{llllll}
\hline $\boldsymbol{l}_{\boldsymbol{1}}$ & $\boldsymbol{t}$ & $\boldsymbol{k}_{\mathbf{0}}$ & $\boldsymbol{k}_{\boldsymbol{d}}$ & $\boldsymbol{W A C C}\left(\boldsymbol{l}_{\mathbf{1}}\right)(\boldsymbol{n}=\mathbf{3})$ & $\boldsymbol{W A C C}\left(\boldsymbol{l}_{\mathbf{1}}\right)(\boldsymbol{n}=\mathbf{5})$ \\
\hline 0 & 0.2 & 0.1 & 0.06 & 0.1 & 0.1 \\
\hline 1 & 0.2 & 0.1 & 0.06 & 0.0928 & 0.0948 \\
\hline 2 & 0.2 & 0.1 & 0.06 & 0.0857 & 0.0898 \\
\hline 3 & 0.2 & 0.1 & 0.06 & 0.0787 & 0.0848 \\
\hline 4 & 0.2 & 0.1 & 0.06 & 0.072 & 0.0799 \\
\hline 5 & 0.2 & 0.1 & 0.06 & 0.0654 & 0.0752 \\
\hline 6 & 0.2 & 0.1 & 0.06 & 0.0587 & 0.0705 \\
\hline 7 & 0.2 & 0.1 & 0.06 & 0.0523 & 0.066 \\
\hline 8 & 0.2 & 0.1 & 0.06 & 0.0461 & 0.0615 \\
\hline 9 & 0.2 & 0.1 & 0.06 & 0.0399 & 0.0571 \\
\hline 10 & 0.2 & 0.1 & 0.06 & 0.0339 & 0.0528 \\
\hline
\end{tabular}

Source:Authoring 


\section{Table 6}

Dependence of WACC on $l_{2}$ for companies at age three $(n=3)$ and five $(n=5)$

\begin{tabular}{llllll}
\hline $\boldsymbol{l}_{\boldsymbol{2}}$ & $\boldsymbol{t}$ & $\boldsymbol{k}_{\mathbf{0}}$ & $\boldsymbol{k}_{\boldsymbol{d}}$ & $\boldsymbol{W A C C}\left(\boldsymbol{l}_{2}\right)(\boldsymbol{n}=\mathbf{3})$ & $\boldsymbol{W A C C}\left(\boldsymbol{l}_{2}\right)(\boldsymbol{n}=\mathbf{5})$ \\
\hline 0 & 0.2 & 0.1 & 0.06 & 0.0998 & 0.1 \\
\hline 1 & 0.2 & 0.1 & 0.06 & -0.0036 & 0.0259 \\
\hline 2 & 0.2 & 0.1 & 0.06 & -0.0804 & -0.0296 \\
\hline 3 & 0.2 & 0.1 & 0.06 & -0.1403 & -0.0732 \\
\hline 4 & 0.2 & 0.1 & 0.06 & -0.1888 & -0.1089 \\
\hline 5 & 0.2 & 0.1 & 0.06 & -0.2289 & -0.1388 \\
\hline 6 & 0.2 & 0.1 & 0.06 & -0.2629 & -0.1643 \\
\hline 7 & 0.2 & 0.1 & 0.06 & -0.2922 & -0.1865 \\
\hline 8 & 0.2 & 0.1 & 0.06 & -0.3178 & -0.2061 \\
\hline 9 & 0.2 & 0.1 & 0.06 & -0.3404 & -0.2235 \\
\hline 10 & 0.2 & 0.1 & 0.06 & -0.3605 & -0.2391 \\
\hline
\end{tabular}

Source: Authoring

\section{Table 7}

Dependence of $W A C C$ on $l_{3}$ for companies at age three $(n=3)$ and five $(n=5)$

\begin{tabular}{llllll}
\hline $\boldsymbol{l}_{\boldsymbol{3}}$ & $\boldsymbol{t}$ & $\boldsymbol{k}_{\mathbf{0}}$ & $\boldsymbol{k}_{\boldsymbol{d}}$ & $\boldsymbol{W A C C}\left(\boldsymbol{l}_{\mathbf{3}}\right)(\boldsymbol{n}=\mathbf{3})$ & $\boldsymbol{W A C C}\left(\boldsymbol{l}_{\mathbf{3}}\right)(\boldsymbol{n}=\mathbf{5})$ \\
\hline 0 & 0.2 & 0.1 & 0.06 & 0.1 & 0.1 \\
\hline 1 & 0.2 & 0.1 & 0.06 & 0.093 & 0.0951 \\
\hline 2 & 0.2 & 0.1 & 0.06 & 0.0864 & 0.0903 \\
\hline 3 & 0.2 & 0.1 & 0.06 & 0.0798 & 0.0856 \\
\hline 4 & 0.2 & 0.1 & 0.06 & 0.0734 & 0.081 \\
\hline 5 & 0.2 & 0.1 & 0.06 & 0.0671 & 0.0765 \\
\hline 6 & 0.2 & 0.1 & 0.06 & 0.0608 & 0.0721 \\
\hline 7 & 0.2 & 0.1 & 0.06 & 0.0548 & 0.0678 \\
\hline 8 & 0.2 & 0.1 & 0.06 & 0.0489 & 0.0635 \\
\hline 10 & 0.2 & 0.1 & 0.06 & 0.043 & 0.0593 \\
\hline
\end{tabular}

Source:Authoring 


\section{Figure 1}

Dependence of a company's weighted average cost of capital (WACC) on the debt-service coverage ratio $\dot{i}_{1}$ for a company at age three $(n=3)$

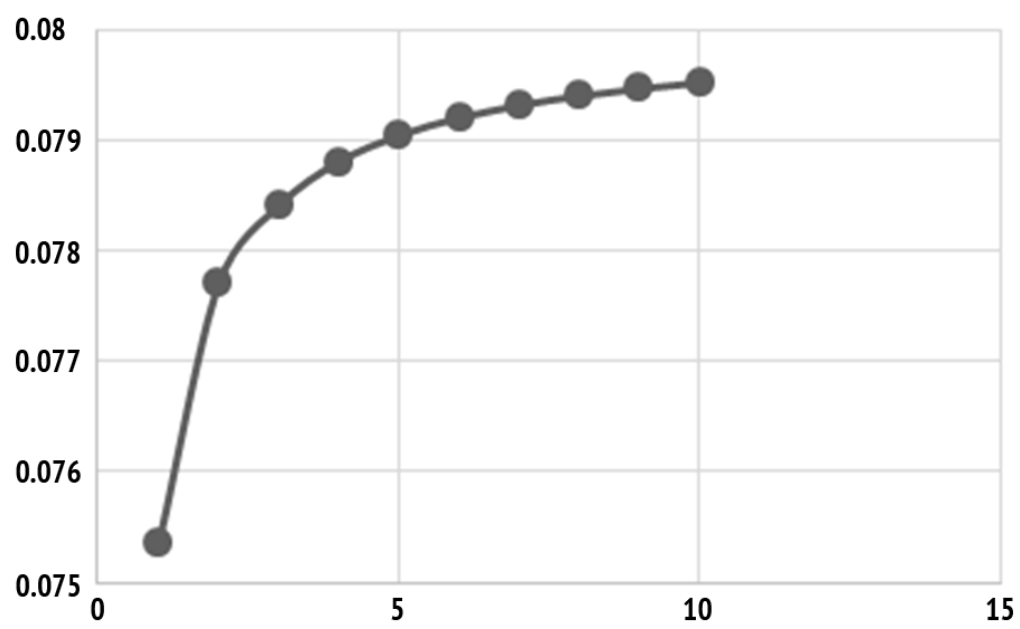

Source:Authoring

\section{Figure 2}

Dependence of a company's weighted average cost of capital (WACC) on the debt-service coverage ratio $l_{1}$ for a company at age five $(n=5)$

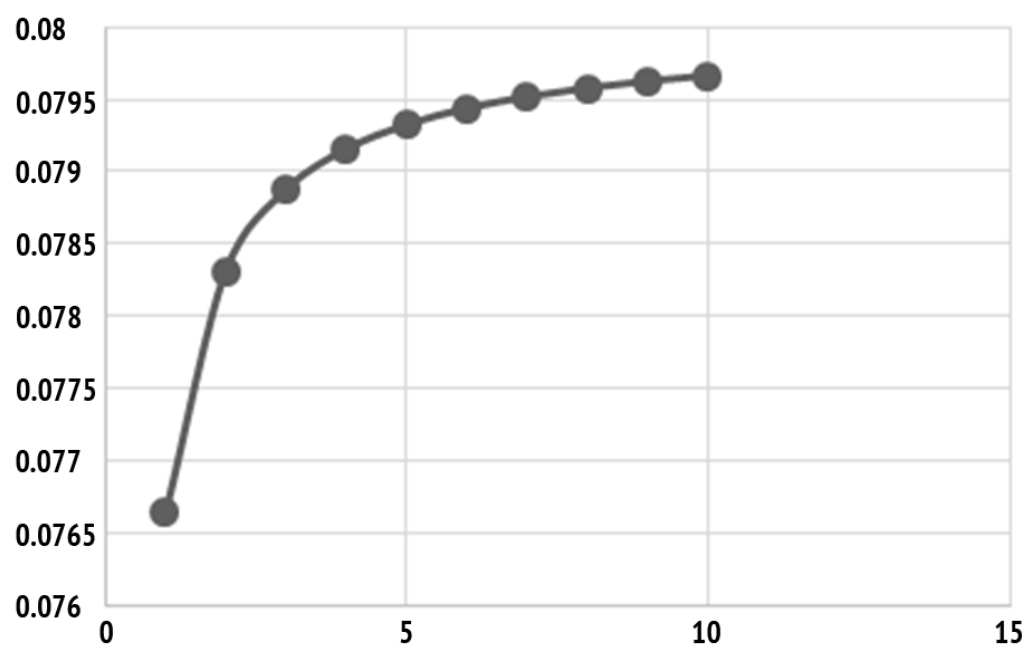

Source:Authoring 


\section{Figure 3}

Dependence of a company's weighted average cost of capital (WACC) on the debt-service coverage ratio $l_{2}$ for a company at age three $(n=3)$

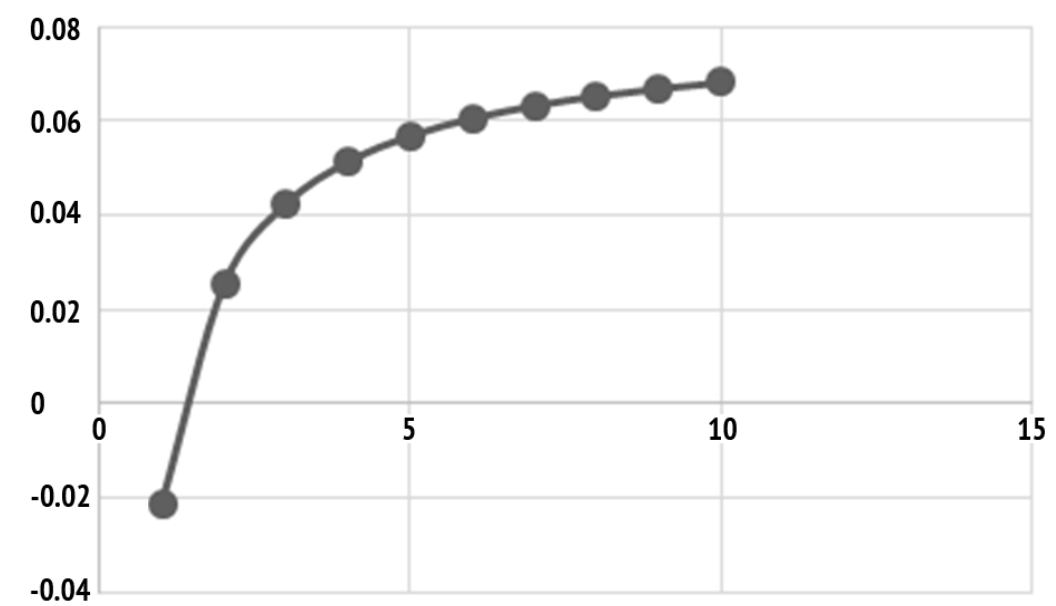

Source:Authoring

Figure 4

Dependence of a company's weighted average cost of capital (WACC) on the debt-service coverage ratio $l_{2}$ for a company at age five $(n=5)$

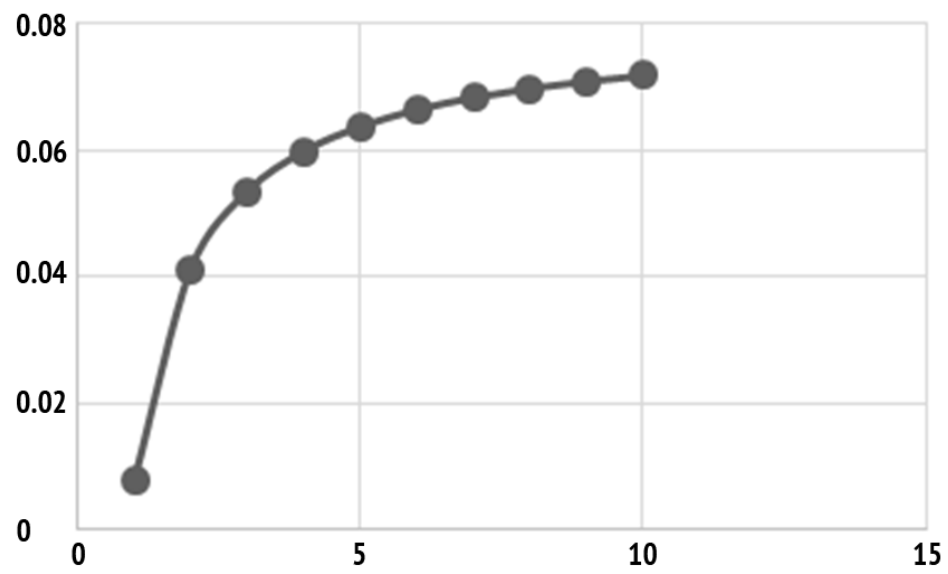

Source:Authoring 


\section{Figure 5}

Dependence of a company's weighted average cost of capital (WACC) on the debt-service coverage ratio $I_{3}$ for a company at age three $(n=3)$

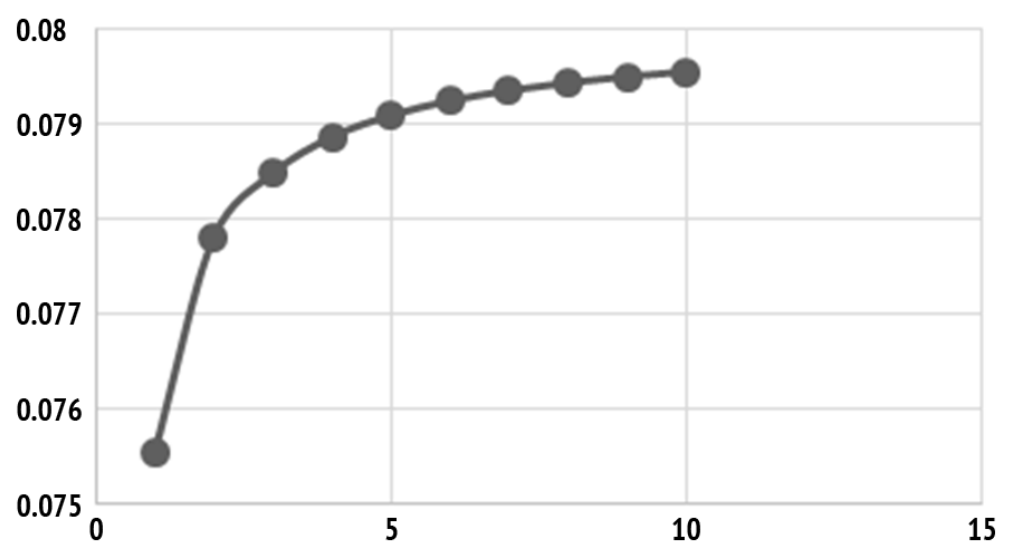

Source:Authoring

\section{Figure 6}

Dependence of a company's weighted average cost of capital $(W A C C)$ on the debt-service coverage ratio $l_{3}$ for a company at age five $(n=5)$

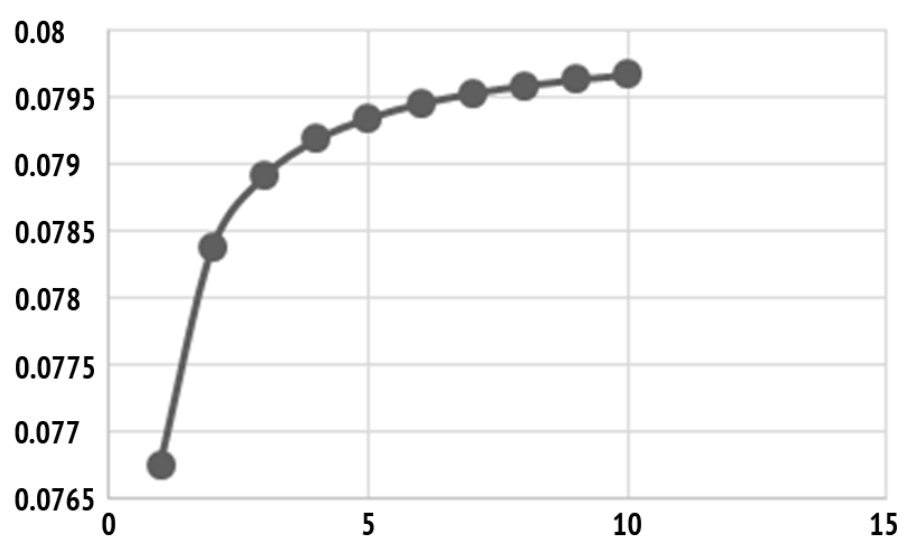

Source:Authoring 


\section{Figure 7}

Dependence of a company's weighted average cost of capital (WACC) on the debt-service coverage ratios $I_{1}, I_{2}, I_{3}$ for a company at age three $(n=3)$

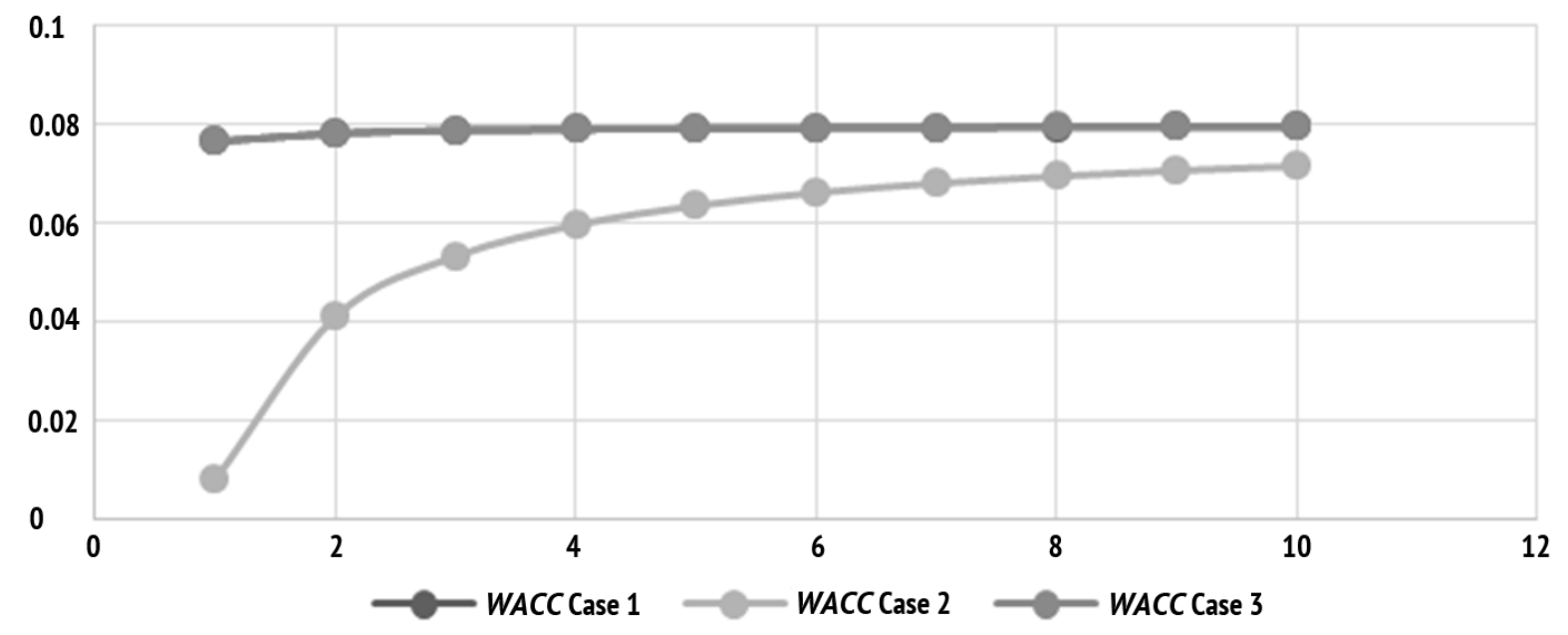

Source:Authoring

\section{Figure 8}

Dependence of a company's weighted average cost of capital (WACC) on the debt-service coverage ratios $l_{1}, l_{2}, l_{3}$ for a company at age five $(n=5)$

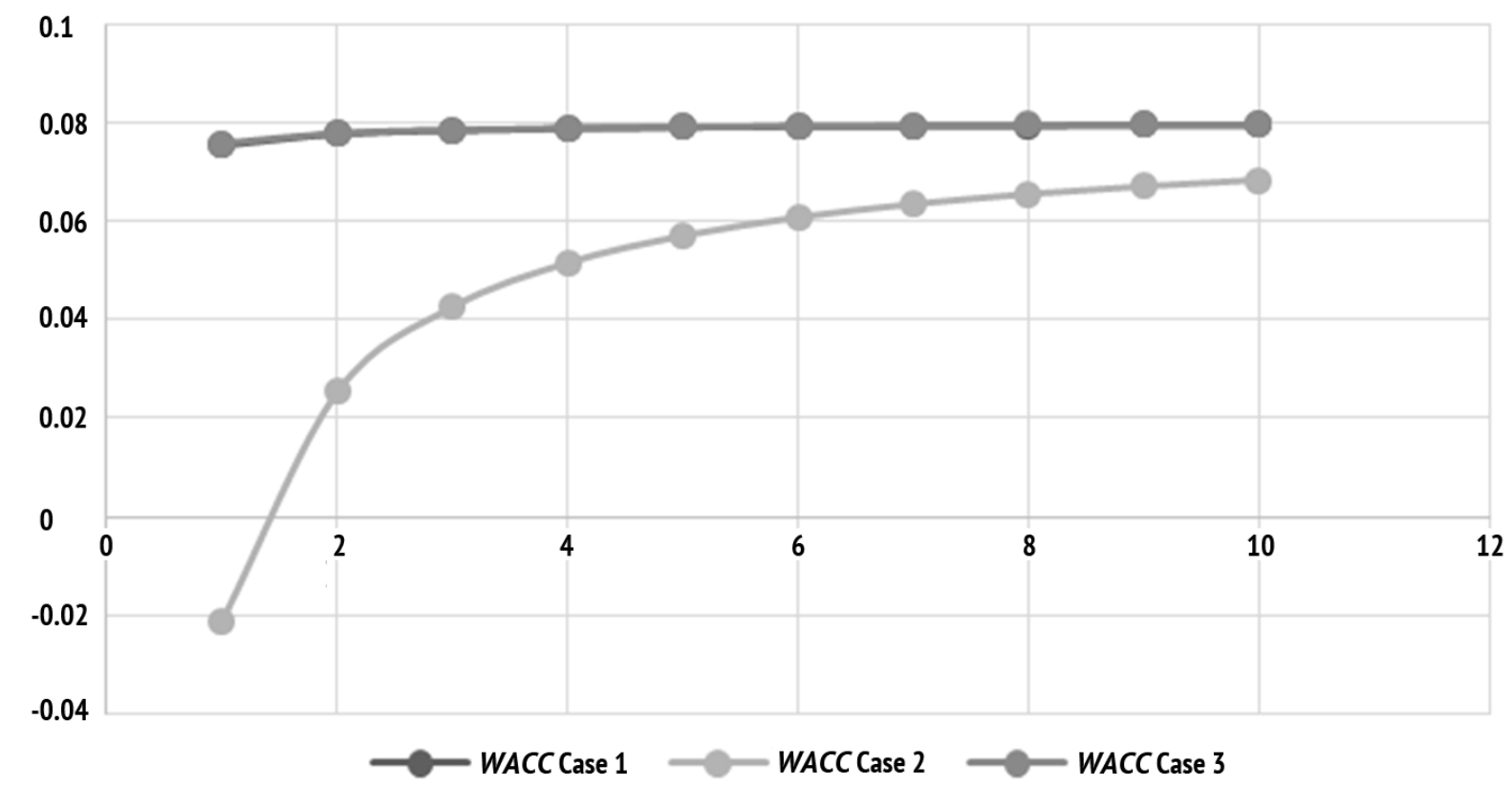

Source:Authoring 


\section{Figure 9}

Dependence of a company's weighted average cost of capital (WACC) on the leverage ratio of debt $l_{1}$ for a company at age three $(n=3)$

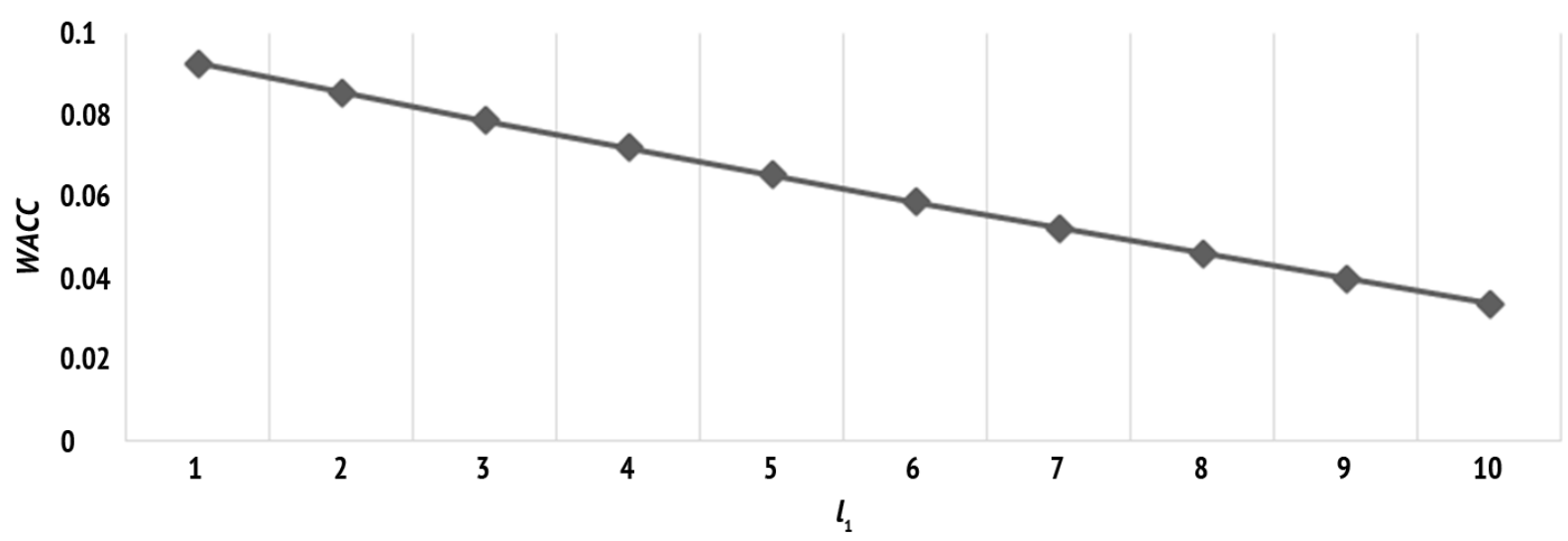

Source: Authoring

\section{Figure 10}

Dependence of a company's weighted average cost of capital (WACC) on the leverage ratio of debt $l_{1}$ for a company at age five $(n=5)$

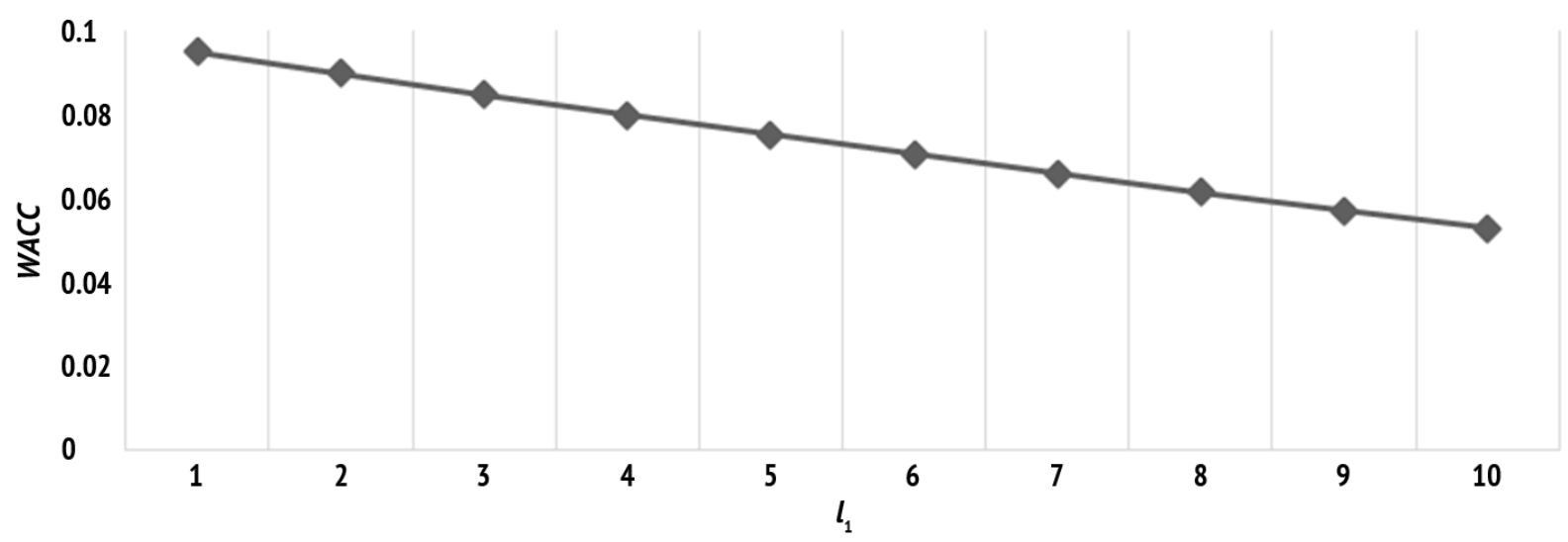

Source:Authoring 


\section{Figure 11}

Dependence of a company's weighted average cost of capital (WACC) on the leverage ratio of loan interests $l_{2}$ for a company at age three $(n=3)$

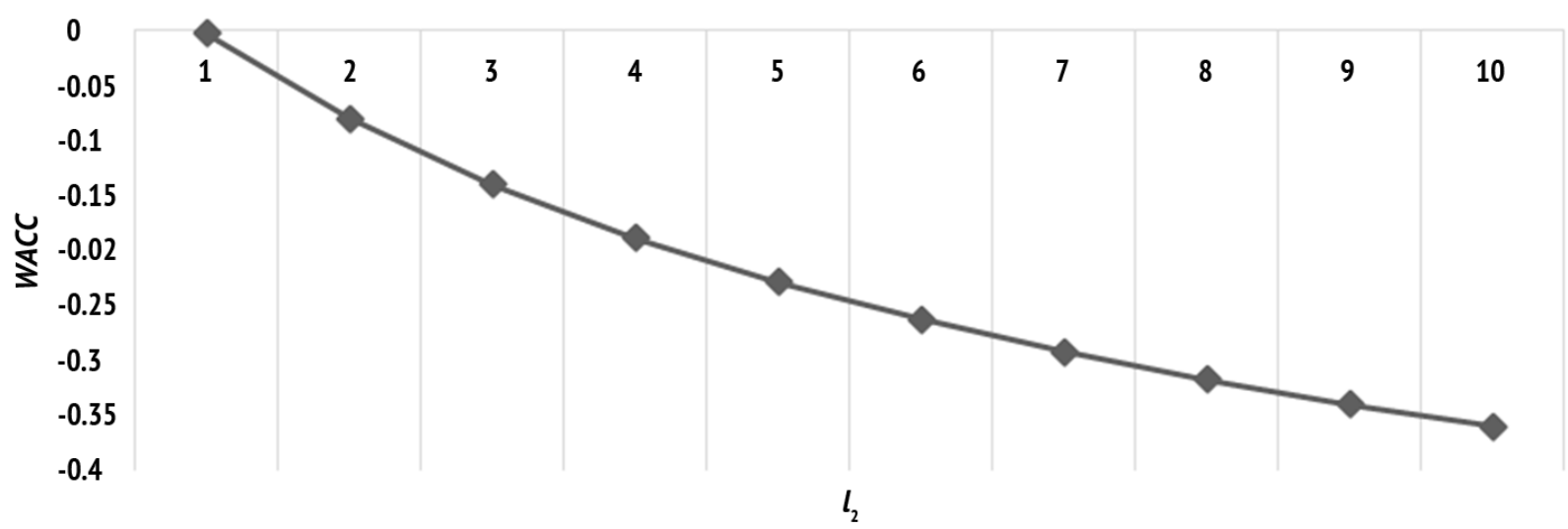

Source: Authoring

\section{Figure 12}

Dependence of a company's weighted average cost of capital (WACC) on the leverage ratio of loan interests $l_{2}$ for a company at age five $(n=5)$

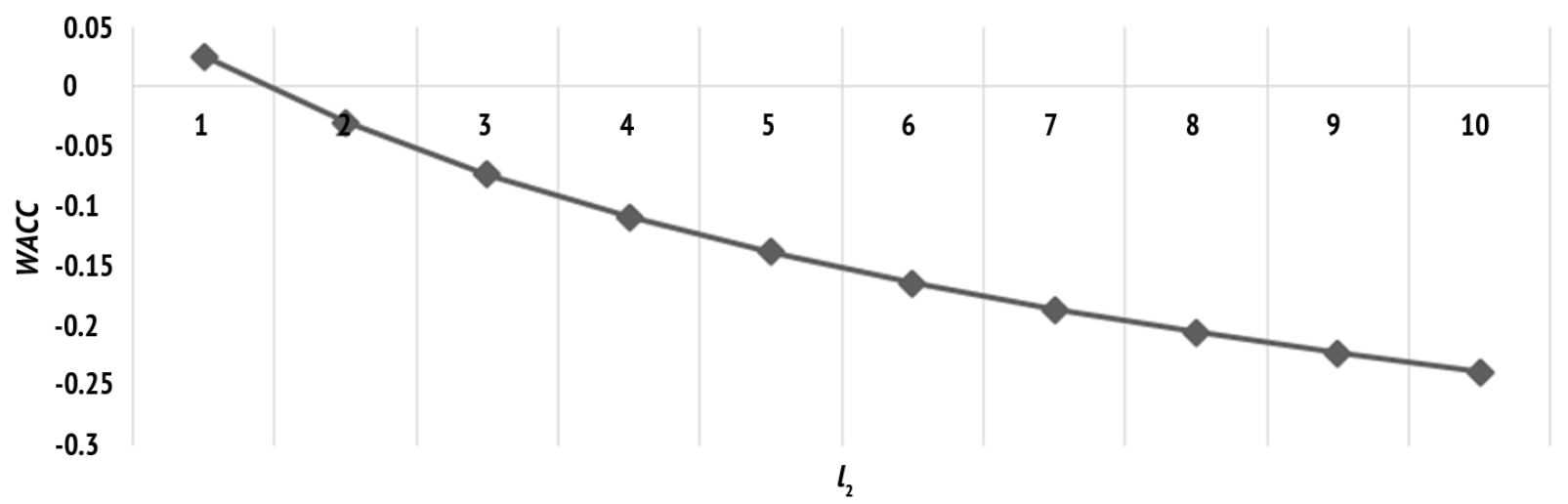

Source:Authoring 


\section{Figure 13}

Dependence of a company's weighted average cost of capital (WACC) on the leverage ratio of debt and interest $l_{3}$ for a company at age three $(n=3)$

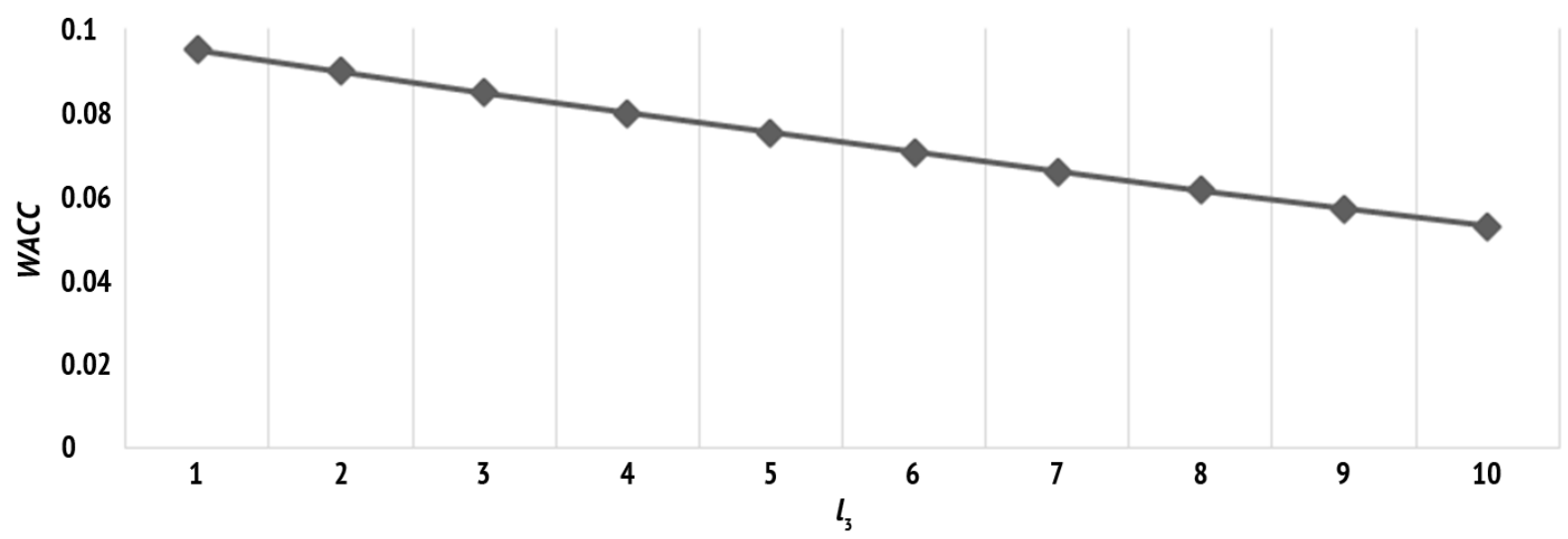

Source: Authoring

\section{Figure 14}

Dependence of a company's weighted average cost of capital (WACC) on the leverage ratio of debt and interest $l_{3}$ for a company at age five ( $n=5$ )

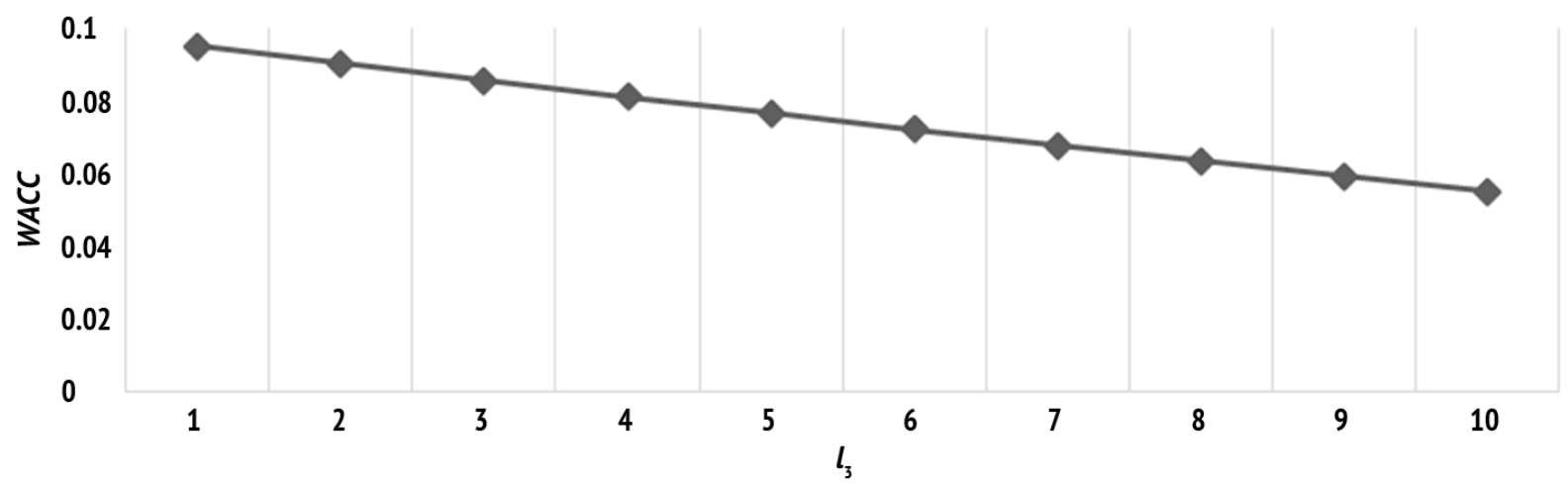

Source:Authoring 


\section{Figure 15}

Consolidated graphs of dependencies of a company's weighted average cost of capital (WACC) on the leverage ratios $l_{1}, l_{2}, l_{3}$ for a company at age three $(n=3)$

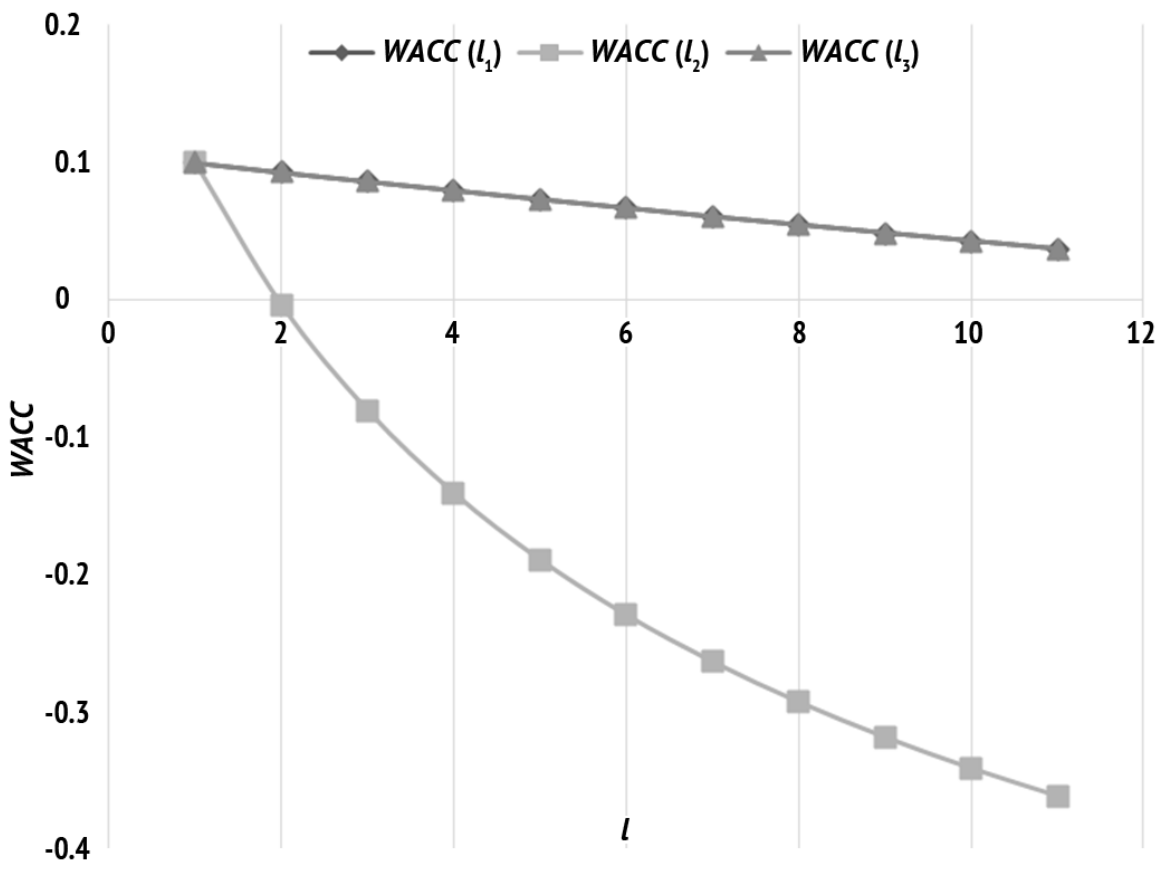

Source:Authoring

\section{Figure 16}

Consolidated graphs of dependencies of a company's weighted average cost of capital (WACC) on the leverage ratios $l_{1}, l_{2}, l_{3}$ for a company at age five $(n=5)$

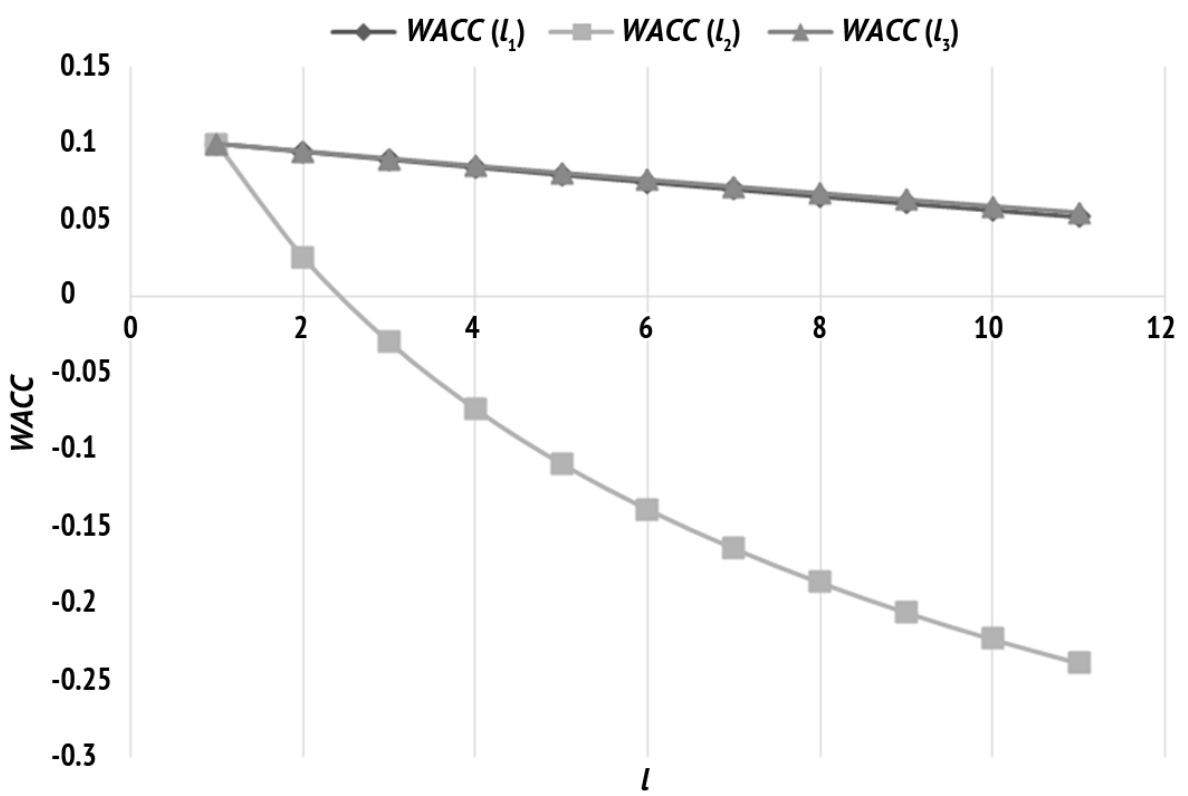

Source: Authoring

Please cite this article as: Brusov P.N., Filatova T.V., Orekhova N.P., Kulik V.L. Improvement of Rating Methodology. Digest Finance, 2018, vol. 23, iss. 2, pp. 191-211. https://doi.org/10.24891/df.23.2.191 


\section{Acknowledgments}

The research was supported by the Russian Foundation for Basic Research as part of Scientific Project No. 17-06-00251A.

\section{References}

1. Brusov P.N., Filatova T.V., Orehova N.P., Eskindarov M.A. Modern Corporate Finance, Investment and Taxation. Springer International Publishing, 2015, 368 p.

2. Myers S.C. Capital Structure. Journal of Economic Perspectives, 2001, vol. 15, iss. 2, pp. 81-102. URL: https://doi.org/10.1257/jep.15.2.81

3. Modigliani F., Miller M.H. The Cost of Capital, Corporate Finance and the Theory of Investment. The American Economic Review, 1958, vol. 48, no. 3, pp. 261-297.

4. Modigliani F., Miller M.H. Corporate Income Taxes and the Cost of Capital: A Correction. The American Economic Review, 1963, vol. 53, no. 3, pp. 433-443.

5. Modigliani F., Miller M.H. Some Estimates of the Cost of Capital to the Electric Utility Industry 1954-1957. The American Economic Review, 1966, vol. 56, no. 3, pp. 333-391.

6. Baker M., Wurgler J. Market Timing and Capital Structure. The Journal of Finance, 2002, vol. 57, iss. 1, pp. 1-32. URL: https://doi.org/10.1111/1540-6261.00414

7. Beattie V., Goodacre A., Thomson S.J. Corporate Financing Decisions: UK Survey Evidence. Journal of Business Finance \& Accounting, 2006, vol. 33, iss. 9-10, pp. 1402-1434.

URL: https://doi.org/10.1111/j.1468-5957.2006.00640.x

8. Bikhchandani S., Hirshleifer D., Welch I. Learning from the Behavior of Others: Conformity, Fads, and Informational Cascades. The Journal of Economic Perspectives, 1998, vol. 12, no. 3, pp. 151-170. URL: https://doi.org/10.1257/jep.12.3.151

9. Brennan M., Schwartz E.S. Corporate Income Taxes, Valuation, and the Problem of Optimal Capital Structure. The Journal of Business, 1978, vol. 51, iss. 1, pp. 103-114.

10. Brennan M.J., Schwartz E.S. Optimal Financial Policy and Firm Valuation. The Journal of Finance, 1984, vol. 39, iss. 3, pp. 593-607. URL: https://doi.org/10.1111/j.1540-6261.1984.tb03647.x

11. Dittmar A., Thakor A. Why Do Firms Issue Equity? The Journal of Finance, 2007, vol. 62, iss. 1, pp. 1-54. URL: https://doi.org/10.1111/j.1540-6261.2007.01200.x

12. Drobetz W., Pensa P., Wanzenried G. Firm Characteristics and Dynamic Capital Structure Adjustment. URL: http://papers.ssrn.com/sol3/papers.cfm?abstract_id=952268

13. Fama E.F., French K.F. Financing Decisions: Who Issues Stock? Journal of Financial Economics, 2005, vol. 76, iss. 3, pp. 549-582. URL: https://doi.org/10.1016/j.jfineco.2004.10.003

14. Fischer E., Heinkel R., Zechner J. Dynamic Capital Structure Choice: Theory and Tests. The Journal of Finance, 1989, vol. 44, iss. 1, pp. 19-40. URL: https://doi.org/10.2307/2328273

15. Graham J.R., Harvey C.R. The Theory and Practice of Corporate Finance: Evidence from the Field. Journal of Financial Economics, 2001, vol. 60, iss. 2-3, pp. 187-243. URL: https://doi.org/10.1016/S0304-405X(01)00044-7

16. Hamada R. Portfolio Analysis, Market Equilibrium, and Corporate Finance. The Journal of Finance, 1969, vol. 24, iss. 1, pp. 13-31. URL: https://doi.org/10.1111/j.1540-6261.1969.tb00339.x 
17. Harris M., Raviv A. The Theory of Capital Structure. The Journal of Finance, 1991, vol. 46, iss. 1, pp. $297-355$. URL: https://doi.org/10.1111/j.1540-6261.1991.tb03753.x

18. Hovakimian A., Opler T., Titman S. The Debt-Equity Choice. Journal of Financial and Quantitative Analysis, 2001, vol. 36, iss. 1, pp. 1-24. URL: https://doi.org/10.2307/2676195

19. Hsia C. Coherence of the Modern Theories of Finance. The Financial Review, 1981, vol. 16, iss. 1, pp. 27-42. URL: https://doi.org/10.1111/j.1540-6288.1981.tb01617.x

20. Jalilvand A., Harris R.S. Corporate Behavior in Adjusting to Capital Structure and Dividend Targets: An Econometric Study. The Journal of Finance, 1984, vol. 39, iss. 1, pp. 127-145. URL: https://doi.org/10.1111/j.1540-6261.1984.tb03864.x

21. Jensen M.C., Meckling W.H. Theory of the Firm: Managerial Behavior, Agency Costs, and Ownership Structure. Journal of Financial Economics, 1976, vol. 3, iss. 4, pp. 305-360. URL: https://doi.org/10.1016/0304-405X(76)90026-X

22. Jenter D. Market Timing and Managerial Portfolio Decisions. The Journal of Finance, 2005, vol. 60, iss. 4, pp. 1903-1949. URL: https://doi.org/10.1111/j.1540-6261.2005.00783.x

23. Korajczyk R.A., Levy A. Capital Structure Choice: Macroeconomic Conditions and Financial Constraints. Journal of Financial Economics, 2003, vol. 68, iss. 1, pp. 75-109. URL: https://doi.org/10.1016/S0304-405X(02)00249-0

24. Kane A., Marcus A.J., McDonald R.L. How Big is the Tax Advantage to Debt? The Journal of Finance, 1984, vol. 39, iss. 3, pp. 841-853. URL: https://doi.org/10.1111/j.1540-6261.1984.tb03678.x

25. Leland H.E. Corporate Debt Value, Bond Covenants, and Optimal Capital Structure. The Journal of Finance, 1994, vol. 49, iss. 4, pp. 1213-1252. URL: https://doi.org/10.1111/j.1540-6261.1994.tb02452.x

26. Post J., Preston L., Sachs S. Redefining the Corporation: Stakeholder Management and Organizational Wealth. Stanford, Stanford University Press, 2002, 376 p.

27. Myers S.C., Majluf N.S. Corporate Financing and Investment Decisions When Firms Have Information That Investors Do Not Have. Journal of Financial Economics, 1984, vol. 13, iss. 2, pp. 187-221. URL: https://doi.org/10.1016/0304-405X(84)90023-0

\section{Conflict-of-interest notification}

We, the authors of this article, bindingly and explicitly declare of the partial and total lack of actual or potential conflict of interest with any other third party whatsoever, which may arise as a result of the publication of this article. This statement relates to the study, data collection and interpretation, writing and preparation of the article, and the decision to submit the manuscript for publication. 